\title{
Bring the Action! Involving Technical Preparatory Students in EFL Reading Classes: An Action Research Study
}

\author{
Gizem Akçor a * \\ a Sakarya University, Department of Foreign Languages Education, Sakarya 54300, Turkey
}

Received 19 July 2017 | Received in revised form 11 September 2017 | Accepted 25 September 2017

\begin{abstract}
During my two-year teaching experience in a university setting one of the biggest problems I faced was to motivate my students at a private (mostly) technical university for the reading classes. It is an undeniable fact that reading classes require EFL learners to have enough skill, confidence, and motivation. However, this requirement is hard to be fulfilled especially for many EFL technical students because their exposure to English is very limited and they have difficulty in meeting some necessary requirements of reading such as critical thinking and use of some strategies and techniques. Consequently, the action research was conducted to involve my technical preparatory students in EFL reading classes. Through this study, I also aimed to develop a deeper and better understanding of my teaching and grow professionally. The question guiding this study was: What happens to my students' attitudes towards reading classes when I integrate visuals, hands-on activities, and competitions into my lessons? After planning the procedures, the action research process involved a pre-test, 4-week intervention, and a post- test to measure the improvement. The statistical data did not show any significant difference in their achievement, but qualitative data taken from observation, field notes, and interviews revealed that integration of visuals and interactive activities into reading classes motivated the students and engaged them more in the classes.
\end{abstract}

(C) 2017 EJAL \& the Authors. Published by Eurasian Journal of Applied Linguistics (EJAL). This is an open-access article distributed under the terms and conditions of the Creative Commons Attribution license (CC BY-NC-ND) (http://creativecommons.org/licenses/by-nc-nd/4.0/).

Keywords: Action research; reading; EFL; motivation

\section{Introduction}

Today, reading is one of the most problematic areas in education (Dreyer \& Nel, 2003). A significant number of students try very hard to deal with complex reading texts, but as Levine, Ferenz, and Reves (2000) express, "the ability to read academic texts is considered one of the most important skills that university students of English as a Second Language (ESL) and English as a Foreign Language (EFL) need to acquire" (p. 1). Reading comprehension is the "essence of reading" (Durkin, 1993);

\footnotetext{
* Gizem Akçor. Tel.: +090-541-531-7401

E-mail address: gizemakcor@gmail.com http://dx.doi.org/......
} 
therefore, acquiring reading comprehension skills is a must not only in academic learning but also in professional life and in lifelong learning (as cited in Levine et al., 2000). Even though reading is a very complex process, the importance of reading comprehension cannot be undervalued. Also, Gambrell, Block, and Pressley (2002) state that "the most important thing about reading is comprehension" (p. 3). Comprehension is beyond the literal meaning of a text and involves a complicated set of other skills and many processes such as using many strategies, cognitive and metacognitive skills. However, many students enter universities unprepared for the demands required by the process of reading. It can be said that reading classes pose problems especially in technical universities' preparatory classes because of students' low self-esteem and engagement in English learning, which has been a typical problem in technical universities for a very long period of time (Shen \& Huang, 2007). Motivating the students in technical universities to engage in the learning process and getting them to participate in reading classes are among the biggest challenges that teachers have to face. One major reason is that these students take fewer hours in learning English, and that these courses are mostly replaced by other courses taught to be more useful. These high school students almost forget English until they become freshmen at universities, which is a frustrating factor because the first year of university require them to study in one-year English preparatory program. They are mostly demotivated and frustrated when attending English courses in preparatory programs since their knowledge of English is very limited. In an attempt to solve this problem, the teacher researcher decided to conduct an action research in her class to get her students to engage in the reading classes actively.

\subsection{Statement of the problem (Initial Reflection)}

\subsubsection{Selecting an issue}

Many EFL learners do not have the skill, confidence, and motivation to be involved in reading classes because their exposure to English is quite limited and reading requires critical thinking and use of some strategies and techniques. As Cheng (2010) suggested for Taiwanese freshmen university students, my students' knowledge of English texts is unsatisfactory and their efficacy in reading is problematic as well. I observed that they are not able to handle the large amount of text, and that they diligently depend on word-by-word reading. Instead of inferring the meaning of the words from context, they rely on their friends or me as their teacher but mostly on bilingual dictionaries or translators, which make them move away from the essence of reading. Soon, they start to moan and groan about the difficulty and dullness of the text or some of them doze off at their desks and some use their mobile phones to check their social media accounts. These kinds of attitudes make both teaching and learning more difficult. The problem mentioned above cause to an urgent concern -how to help struggling EFL technical students read the texts in their course books willingly.

\subsubsection{Collecting information about the issue}


After selecting an issue to examine in more detail, I started to self-observe my own reading classes and talked to my colleagues about the issue. Most of them had the same problem. Over time I realized that I was not offering any variety in my reading classes. Most of the time, because of time and classroom management issues, I was avoiding competitions or games. Generally, I followed a routinized program. After asking students to close their books and take a piece of paper, I got them to take notes of important points they caught while listening to the text. Then, we discussed their notes, analyzed the text in detail, and answered the comprehension questions, which was a very boring process for my students and also for me. Their moans and groans demotivated me as well and I was afraid of coming up with some creative ideas in case they may not show any interest. Luckily, I came to my senses and asked my students the reason why they are demotivated and do not pay any attention to the reading texts. The reading texts were boring and long with lots of unknown vocabulary, they answered with one voice. Thus, I decided to review the related literature about motivation and reading comprehension. My starting point was how to motivate my students for reading, and I decided to integrate some visuals, hands-on learning activities, and competitions into my lessons.

\subsection{Purpose of the Study and Action Research Question}

Some of the purposes of this study are to investigate my own practice as a teacherresearcher, bring about some changes in my classroom teaching and learning, to develop a deeper and better understanding of my teaching process, to grow and learn professionally by making use of my own experiences, and to gain a better control over my own teaching practice (Farrel, 2007). My primary purpose, on the other hand, is to help my struggling students read the texts in their course books willingly, which led me to ask the following question to guide this project: What happens to my students' attitudes towards reading classes when I integrate visuals, hands-on activities, and competitions into my lessons?

\subsection{Significance of the Study}

This study is an action research explained by Burns as a study which "involves teachers taking 'action', often in the form of an intervention to systematically investigate, through 'research', a classroom issue they feel is worth exploring in order to better understand or enhance an aspect of teaching or learning" (as cited in Edwards \& Burns, 2016). Developing a 'reflective mindset' (Goodnough, 2011; Seider \& Lemma, 2004) and also better and deeper knowledge and personal theories about and out of their own teaching process, increasing awareness and empowerment (Atay, 2008; Wyatt, 2011) are among the benefits of action research to the teacher researcher. Furthermore, Edwards and Burns (2016) remarked that classroom practitioners become more self-confident, reflective, empowered, and flexible in their way of teaching thanks to action research they conducted. The benefits listed above show the significance of the action research per se. 


\subsection{Literature Review}

Reading is one of the most crucial skills for students to acquire in their daily life to keep being updated about the latest issues and in their academic life because many universities require students to study in English preparatory programs for a year. Reading is highly important especially for preparatory students at University of Turkish Aeronautical Association (UTAA) because they are going to continue their departments in English and reading their subject matters in English will be unavoidable. However, I noticed that technical preparatory students in my class faced a lot of problems while reading in English because of their low motivation and engagement. When asked, they claimed that this was mainly because of the dullness of long reading texts with full of unknown vocabulary.

Being an interactive process, reading is defined by Alderson (2000) as a "process of interaction between a reader and the text" (p. 3). Nuttall (1996) believes that reading is not looking at sentences and words and checking for the meanings one-by-one, but going beyond them and understanding them intellectually. Jiménez's definition (2000) for reading as "the learners' ability to interpret or work out the meaning of a written text and react towards it as a result" (as cited in Castillo \& Bonillo, 2014, p. 70), on the other hand, leads us to the fact that reading comprehension is necessary in this process. Reading comprehension is a very complex process, though. Since it has been found that teaching reading strategies results in better reading comprehension, many studies have been conducted to see the effect of teaching reading strategies on reading comprehension skills (Blickenstaff, Hallquist, \& Kopel, 2013; Cadena, 2006; Chou, Wang, \& Ching, 2012; Küçükoğlu, 2013; Song, 1998).

This complex nature of reading comprehension process may demotivate students easily. Therefore, it is important to motivate the students and to keep them eager and enthusiastic for reading. Motivation is one of the most effective things to shoulder the reading process (Grabe \& Stoller, 2002; Castillo \& Bonilla, 2014) especially for my students who are particularly demotivated to read and engage in the reading classes. Many studies revealed the great impact of motivation on reading comprehension (Cox \& Guthrie, 2001; Guthrie, Wigfield, Metsala, \& Cox, 1999; İçmez, 2009; Knoll, 2000; Morgan \& Fuchs, 2007).

Researchers have claimed that highly motivated students can overcome reading challenges easily. Guthrie et al. (1999) argued some instructional practices that might be helpful in boosting reading motivation and comprehension: promoting social interactions related to reading, enhancing a friendly and non-threatening teacherstudent(s) relationship, and using hands-on activities are among these practices. Use of visuals, hands-on activities, and competitions in reading classes may increase the students' motivation.

As Bowen (1982) and Bellver (1989) suggested, teachers can create a strong connection between student and the reading text by using visual aids and encourage them to read the texts enthusiastically, which helped them to get the abstract ideas 
easily (as cited in Yunus, Salehi, \& John, 2013). The visuals, just like metal frames of a building (Carney \& Levin, 2002) and as a bridge between the native language and English, support the students during the reading process and help them understand the texts without needing any translations or excessive and long explanations (Brinton, 2001). Likewise, competitions can be used to engage students. As Gordon and Gillespie (2006) suggested, making students into enthusiastic, flexible, adaptable, and collaborative individuals are among some positive results that can be attained thanks to a competitive environment.

\section{Method}

\subsection{Planning}

After selecting the issue I wanted to touch upon, I did some research on the related literature and decided to integrate three practices into my lessons: use of visuals, hands-on activities, and competitions. I hoped these practices to motivate my students to engage in the reading classes.

After observing what was going on in my classes and getting the opinions of my students, I planned my action and decided on the intervention procedures. The action will take place in the treatment process. Students will get a pre-test on reading just before the treatment process and a post-test just after the treatment to measure the improvement and to see if there is a positive change in their achievement. The treatment process will be 4 weeks. The teacher will make a lesson plan for each week appropriate for the aim of the research. These plans will be designed for the reading lessons in the course book 'Top Notch 2 and 3, 3rd edition.' in which each unit consists of preview and review sections and four lessons, and Lesson 3 or Lesson 4 is for reading texts. After the treatment process, the students will be given a post-test and at least 5 students will be interviewed on a volunteer basis. After each week's intervention lesson, the teacher-researcher will take notes of what she observed.

\subsubsection{Setting and Participants}

I was an instructor in Foreign Languages Department at UTAA, and I, as a teacher-researcher, conducted the action research in my own class which included 21 students. Most of the students were technical students, which means they are going to study in either engineering or flight training departments. My claim is that being technical students might be the primary reason of low motivation and engagement in reading classes.

\subsubsection{Instruments}

As for data collection tools, pre and post-tests, observation, field notes, and interview will serve as the tools for gathering data. The statistical analyses of the pretest and post-test data will be conducted by using the Statistical Package for Social Sciences (SPSS) version 21. 


\subsection{Action (Data Collection Procedures)}

In the beginning of my research I gave my students a pre-test based on the reading text in Unit 9 Lesson 4 in the course book Top Notch 2 to measure their performance before implementing the intervention. This test consisted of the reading text (Top Notch 2, U9 L4) with three parts. The first part is a matching the word with the appropriate definition activity with 7 options. The second part consists of 9 true-false questions. Lastly, the third part includes three multiple choice questions. Students were not informed about the quiz. Later on I used these results to record the change.

In the following four weeks I practiced the activities for the reading text of each week I had planned beforehand. I especially tried to integrate some visuals such as pictures, photos, or videos into my each lesson to get my students' attention. The program of intervention was just like this:

Table 1. Implementation of the intervention

\begin{tabular}{|c|c|}
\hline \multirow[t]{11}{*}{$1^{\text {st }}$ Week } & Top Notch 2/ Unit 10 -Ethics and Values \\
\hline & Lesson $4-$ Discuss acts of kindness and honesty \\
\hline & $\begin{array}{l}\text { Before reading the text (see Appendix } A \text { ), discuss the title of the lesson } 4 \text {. Show the power } \\
\text { point presentation that includes some photos showing some acts of kindness and honesty } \\
\text { and get the students to guess the context and to talk about their feelings and opinions. }\end{array}$ \\
\hline & Watch the related videos and talk about the students' feelings and opinions: \\
\hline & https://www.youtube.com/watch?v=PT-HBl2TVtI \\
\hline & https://www.youtube.com/watch?v=oeph_eX_pVw \\
\hline & https://www.youtube.com/watch?v=KMYrIi_Mt8A \\
\hline & Students read the text individually and silently in the given time. \\
\hline & The teacher shows a PPT for unknown vocabulary \\
\hline & $\begin{array}{l}\text { Competition Time! - The class is divided into two groups. On the walls at the back of the } \\
\text { class the printed versions of the reading texts are hung. For each question one student from } \\
\text { each group comes to the teacher desk on which a bell is placed. The students see the } \\
\text { question from the PPT, and the student who has rung the bell first has a chance to answer } \\
\text { the question. If s/he answers correctly, the group gets one point. If not, the other student } \\
\text { will have a chance to answer the question. The group which collects more points will be the } \\
\text { winner. (for the questions: see Appendix B) }\end{array}$ \\
\hline & $\begin{array}{l}\text { The teacher puts emphasis on the parts the students have difficulty in, and finally the class } \\
\text { answers the questions in the book. }\end{array}$ \\
\hline \multirow[t]{7}{*}{$2^{\text {nd }}$ Week } & Top Notch 3/ Unit 1- Make Small Talk /Lesson 4- Discuss how culture changes over time \\
\hline & $\begin{array}{l}\text { Before reading the text (see Appendix } C \text { ), discuss the title and get students to give some } \\
\text { examples from their lives. }\end{array}$ \\
\hline & $\begin{array}{l}\text { For the warm-up part, go to the website with the title 'Remembering being a child in } 90 \mathrm{~s} \\
\text { with } 200 \text { photos'. The photos on the website are good examples of cultural changes over } \\
\text { time. Students express their feelings and opinions about the photos. }\end{array}$ \\
\hline & http://onedio.com/haber/200-fotografla-90-lar-cocuklarini-gecmise-goturecek-dev-galeri- \\
\hline & $\underline{344605}$ \\
\hline & Students read the text individually and silently in the given time. \\
\hline & $\begin{array}{l}\text { Competition Time! -The class is divided into four groups. Each group gets a piece of paper } \\
\text { and a pen. They close their books and put them aside. The teacher reads the questions } \\
\text { which are True-False or short answer, and the groups write their answers on their papers in } \\
15 \text { seconds and raise them up. Each correct answer is } 1 \text { point. The group which collects more } \\
\text { points will be the winner. (for the questions: see Appendix D) }\end{array}$ \\
\hline
\end{tabular}


The teacher puts emphasis on the parts the students have difficulty in, and finally the class answers the questions in the book.

$3^{\text {rd }}$ Week Top Notch 3/ Unit 2- Health Matters/ Lesson 3- Discuss types of treatments

Before reading the text (see Appendix E), discuss the title.

Ask students to think of some treatment types they know and to look at the pictures in the reading text and ask them what they know about the pictures. Make them guess the context of each text.

Students read the text individually and silently in the given time.

Hands-on Activity Time! - The class is divided into seven groups of 3. They are given colored papers, a set of definition cards, a set of information cards, and a chart (see Appendix F). The groups draw their topic from a bag. They paste their topics (e.g., conventional medicine, homeopathy, acupuncture, herbal therapy, and spiritual healing) on the top of the colored page. Next, they find the correct definition card and two information cards from the sets of cards and paste them on their colored paper as well. They also paste and fill the chart according to the information in the text. Lastly, they draw a picture related to their topic and paste it on their poster, too.

Each group's poster (see Appendix $G$ ) is hung on the wall. Each group comes to the board and explains their topic, gives the definition, inform the class about the important issues, and describe their drawings to their friends.

The teacher answers the questions of students and clarifies the parts the students could not get.

$4^{\text {th }}$ Week $\quad$ Top Notch 3/ Unit 7 -Holidays and Traditions/ Lesson 3- Exchange information about holidays

Before reading the text (see Appendix $H$ ), discuss the title.

Ask students the holidays in their culture and other cultures. Ask them to look at the photos in the reading text and ask if they know anything about them.

Tell students that firstly they are going to read the first text and then they are going to watch a video about Ramadan. Ask them to take notes of some similarities and differences, between the text and the video and interesting things they have learned from the text or the video. After finishing reading the text and watching video, they will discuss about their notes. Then, the same process will be done with the other two texts.

Ramadan: https://www.youtube.com/watch?v=0ikpzGMoB5Y

The Chinese New Year: https://www.youtube.com/watch?v=_u-R-aIq3_E

Simon Bolivar's Birthday: https://www.youtube.com/watch?v=8HFiSUjEzVs

Competition Time! -After discussing the texts, the students are divided into two groups. For each question one student from each group comes to the teacher desk on which a bell is placed. The students see the question from the PPT, and the student who has rung the bell first has a chance to answer the question. If s/he answers correctly, the group gets one point. If not, the other student will have a chance to answer the question. The group which collects more points will be the winner. (for the questions: see Appendix I)

After implementing intervention, I gave my students a post-test based on the reading text in unit 5 Lesson 3 in the course book Top Notch 3 to measure the change. This test included the reading text (TN3, U5, L3) with three parts. The first part is a matching the word with the appropriate definition activity with 7 options. The second part consists of 7 true-false questions. Lastly, the third part includes 5 multiple choice questions. Students were not informed about the quiz. Later on I used these results to record the change. The level and the type of the test were the same to get more reliable results.

\section{Findings and Discussion}

\subsection{Quantitative Data}


After the intervention these were my results. For analyzing the gathered data, Paired T-test from SPPS was used. Pallant (2010) suggests that this technique is suitable for pre-test/ post-test experimental designs.

Table 2. Paired T-test results of pre and post tests

\begin{tabular}{llllll}
\hline & & Mean & N & Std. Deviation & Std. Error Mean \\
\hline Pair 1 & PreTest & 12,0952 & 21 & 3,93579 &, 85886 \\
& PostTest & 13,6190 & 21 & 4,52190 &, 98676 \\
\hline
\end{tabular}

Table 3. Paired samples test results

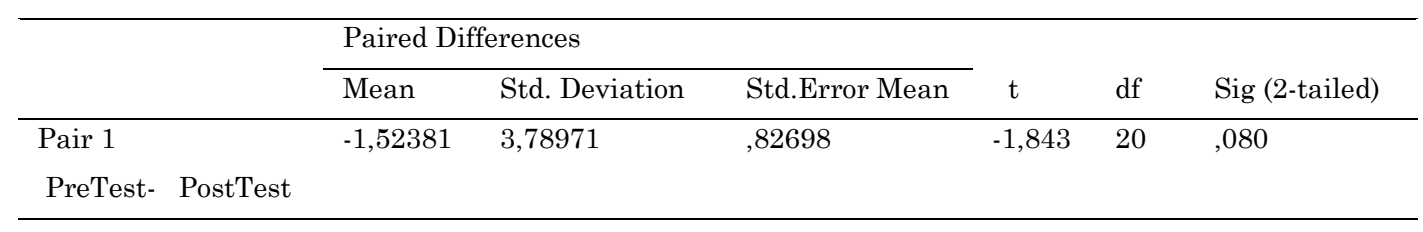

To be able to interpret the date correctly, we need to look in the final column 'Sig. (2-tailed)' in the table labeled 'Paired Samples Test'. If the value in this section is less than .05 , we can conclude that there is a significant difference between pre-test and post-test. However, my value '.080' is bigger than .05, which shows that there is no significant difference between two scores. This might be resulting from the difference in the number of questions or from the time limitations. I might have gotten different results if the intervention process had been longer and I had taught reading strategies for comprehension.

\subsection{Qualitative Data}

\subsubsection{Observation}

Even though numerical data says the opposite, my observation is completely different. After each lesson, I wrote down my observation which shows that I reached my aim. Integration of visuals, hands-on activity, and competitions changed the atmosphere of the class and the attitudes of my students. Starting each reading lesson with visuals and interesting videos attracted their attention, and they were more motivated in the rest of the lesson and had something to say about the topic. The interactive activities kept their eagerness alive. Their urge to win the competition made them read the text. After each lesson, they left the class with a big smile on their face, which is quite motivating for me. I remember the times when all the students left the class with moans and groans. The most interesting thing I observed happened during the fourth week of intervention when we did a hands-on activity. When I explained the activity and gave the instructions, most of the students complained about it since they were not kindergarten students. However, they were so absorbed in the activity that they even forgot the break time. They put their works 
on the wall carefully and presented them successfully to the class. They actually enjoyed it.

\subsubsection{Interviews}

In order to reach more rich data and provide more answers in depth, I wanted to support my study with a qualitative method. Therefore, I interviewed nine of students. The interviews helped me "to gain insight into things such as people's opinions, feelings, emotions and experiences" (Dörnyei, 2007, 173). During the interview, I asked my students to compare the reading activities we did before and the ones we did during the four weeks. Some of my questions: Which technique was effective for you: reading the text silently and answering the questions one-by-one or reading within a group and doing interactive activities? How did you feel during the interactive activities? Were they useful? Do you prefer silent reading by yourselves or group work?

During the interview, my students complained about the dullness of the reading texts again. One of the female students suggested that they can try to read some texts about their departments because they study at a technical university. Most of the students found the interactive activities and visuals enjoyable and useful stating as following:

Student 1:

"Interactive activities are better for us. They help us remember the things easily. With my partner we really tried to understand the text. We found the main idea. I really liked the poster presentation activity, maybe because I like doing handwork. It really helped me to understand better. Both watching videos and reading the text were very effective for me, especially the videos we watched about the festivals in the last week. I do not like reading by myself in the class because our paces are different, and some people finish reading quickly and start talking, so I cannot focus. The video about festivals helped me a lot. While reading the text, I took a note of important points. When I see them on the video, they stuck in my mind".

\section{Student 4}

"I do not find reading individually effective because we get distracted after a while. Some of my friends start to talk or I see lots of unknown words, which make me not to understand the text. The most efficient one for me was poster-presentation because I could ask my friend the words I do not know. Competitions are very useful especially in the last hours, but sometimes we lose lots of time. For example, I learned the word 'moral dilemma' from the video that we watched. It helped me a lot. In fact, I did not read alone, but I had to read the texts within a group".

Student 5

"I really like competitions especially when I do not have energy because competitions help me to come to my senses. I do not like preparing posters because these kinds of 
activities are at a level of kindergarten. On the other hand, they helped me to discover my ability at these handcrafts things. I did not know I was good at them before".

Student 6

"I prefer reading in groups because I can get help from my friends. I am not good at reading alone. Interactive activities and visuals help me remember better. When I read all by myself, I do not remember anything because my basic knowledge of English is not very sufficient and I cannot focus easily because of not being able to understand most of the things in a text. Normally I cannot tell anything about Bolivar in English, but thanks to video I have some things to say".

Student 7

"I definitely prefer interactive activities because my English is bad. These kinds of activities are more useful and enjoyable for me because I can get help from my friends. While studying alone, I tend to sleep or use my mobile phone".

\section{Student 9}

"My basic knowledge of English is not good, so when I encounter many unknown words, I easily get distracted. The competitions and activities help me spread positive energy. I get motivated. The videos and visual helped me learn many words and remember the context easily. I can get help from my friends during the interactive activities".

One of the male students remarked his opinion with these words:

Student 2

"As a class, we are not ready for the group work. Some problems arise when the group is formed with a lot of people. For example, some people do not take over the responsibility. When we are groups of two or three, I enjoy more. That's why, I enjoyed the poster presentation more. Interactive activities are more useful for us. When studying individually, we can get distracted very easily, but group work helps us take over the responsibility to have a clear conscience and participate in the lesson"

Two of the male students enjoy the competitions in terms of fun, but they prefer to study individually. This point of view is illustrated by following words:

Student 3

"I like reading alone. When there is a competition, the feeling of winning dominates the atmosphere of the classroom, so we do not focus on the text. Likewise, when we are doing a hands-on activity, we focus mostly on the drawing, cutting the papers, which drifts us away from the subject. Competitions help us to have fun during the lesson".

\section{Student 8}

"I really enjoy competitions, but studying individually is more useful for me. I do not find true false activities very useful, but giving short answers were quite useful. I learned many things". 
With the help of interviews, I was able to see that my observation corresponds to students' points of view. Most of them enjoyed the interactive activities and found visuals and videos very useful especially in remembering the unknown vocabulary. They expressed that they participated more compared to studying individually because they easily get distracted while studying alone. They tend to use their mobile phones or sleep. However, with a group, they take over their responsibility and act accordingly. They help each other as well. At the same time, they have fun. Even students who like self-study stated that they had fun during the activities.

\section{Conclusion and Reflection}

The present study explored if the integration of visuals, hands-on activities, and competitions into EFL reading classes changed the attitudes of technical university students. Even though statistical data says the opposite, my qualitative data shows that I achieved my goal. I was pleased to see the improvement and to see that I managed to involve my technical students in reading classes. Looking at the post-test results, half of the students progressed, but the difference is not significant. I believe this study could have yielded better results if I had more time for the intervention process since I could integrate a range of interactive activities and teach my students reading strategies.

In conclusion, visuals and interactive activities such as hands-on group works and competitions help me involve the low motivated technical students in the reading classes. Visuals attracted their attention in the first place, and then they came to their senses with the help of positive effect of group work. These activities prevented most of the students from using their mobile phones and sleeping. Instead, they took over the responsibility and made sufficient efforts to engage in the text. They asked their peers' help as well.

Pachtman and Wilson (2006) expressed that giving our students a chance to select what to read is a great motivator to read the material. However, what are we supposed to do if we do not have an opportunity to be selective about the reading materials? This study helped me realize that we can offer our students a range of activities even if we cannot provide them with a choice of texts. We, as teachers, need to discover the alternative ways of involving these students in the classes. We expect our students to be intrinsically motivated, but in reality it is mostly our responsibility to motivate and lead them because most of them are demotivated and avoid reading.

I will continue to utilize this strategy in my future classes in order to improve my students' study skills and prepare them for college and the working world.

Surely this study has some limitations. The present study was conducted with only one class, which might make generalization of the results difficult. In fact, this results from the nature of action research which is "empowering teachers to monitor their own practices in a more autonomous manner with a vision of challenging improving their own techniques of teaching through their own participatory research" as Kayaoğlu (2015, p. 140) reported. Still, similar studies in different and larger EFL 
reading classes might be carried out to investigate if the practices mentioned in this study work for other students, too. Other practices thought to be useful might be tried to motivate students to read their assigned texts and the results can be shared.

As Biesta and Burbules (2003) argue, educational problems are unique, and we can only manage to reach at unique responses by examining our own educational practice rather than top-down enforcements. It is highly suggested that teachers in action will bring some action to their own classes by conducting their own studies.

\section{Acknowledgements}

The completion of this study could not have been possible without the expertise of Prof. Dr. Arif Sarıçoban. A debt of gratitude is owed to him for his guidance. I would also like to express my gratitude to the University of Turkish Aeronautical Association for letting me conduct this study and thank my well-beloved colleagues and dear teachers for their invaluable comments on this study.

\section{References}

Alderson, J. C. (2000). Assessing reading. Cambridge, UK: Cambridge University Press.

Atay, D. (2008). Teacher research for professional development. ELT Journal (62)2,139-47.

Biesta, G. J. J., \& N. C. Burbules. (2003). Pragmatism and Educational Research. Lanham, MD: Rowman \& Littlefield

Blickenstaff, J., Hallquist, E., \& Kopel, K. (2013). The effects of reading strategies in comprehension for elementary age learners. Retrieved from: http://sophia.stkate.edu/cgi/viewcontent.cgi?article=1001\&context=maed

Brinton, D.M. (2001). The use of media in language teaching. In M. Celce-Murcia (Eds.), Teaching English as a second or foreign language (pp.459-475). Boston: Heinle and Heinle.

Cadena, C. M. Z. (2006). Effectiveness of reading strategies and improving comprehension in young ESL readers (Master's Thesis, Universidad del Norte, Barranquilla.) Retrieved from http://manglar.uninorte.edu.co/bitstream/handle/10584/718/45686016.pdf;jsessi onid=FD7D698A112EB371940F6D8DBAEAADAB? sequence=1.

Carney, R.N, \& Levin, J.R. (2002). Pictorial illustrations still improve students' learning from text. Educational Psychology Review,14(1), 5-26.

Castillo, A. I., \& Bonilla, J. S. (2014). Building up autonomy through reading strategies. PROFILE Issues in Teachers' Professional Development, 16(2), 67-85. doi: https://doi.org/10.15446/profile.v16n2.39904.

Chou, C. H., Wang, S., \& Ching, G. S. (2012). Balanced reading instructions: An action research on elementary cram school students. International Journal of Research Studies in Language Learning, 1(1), 3-20.

Cox, K. E., \& Guthrie, J. T. (2001). Motivational and cognitive contributions to students' amount of reading. Contemporary Educational Psychology, 26(1), 116-131.

Dörnyei, Z. (2007). Research methods in applied linguistics: Quantitative, qualitative, and mixed methodologies. Oxford: Oxford University Press.

Dreyer, C., \& Nel, C. (2003). Teaching reading strategies and reading comprehension within a technology-enhanced learning environment. System 31(3), 349- 365. 
Durkin, D., (1993). Teaching them to read (6 $6^{\text {th }}$ ed). Boston, MA: Allyn \& Bacon.

Edwards, E., \& Burns, A. (2016). Language teacher action research: achieving sustainability. ELT Journal, 70(1), 6-15. doi:10.1093/elt/ccv060.

Farrel, T. S. C. (2007). Reflective language teaching: From research to practice. London: Continuum.

Gambrell, L., Block, C. C., \& Pressley, M. (2002). Improving comprehension instruction. Newark, DE: Jossey-Bass.

Goodnough, K. (2011). Examining the long-term impact of collaborative action research on teacher identity and practice: the perceptions of K-12 teachers. Educational Action Research 19(1), 73-86.

Gordon, E., \& Gillespie, W. (2006). Competition in political pcience pedagogy. Academic Exchange Quarterly, 10(4), 1-6.

Grabe, W., \& Stoller, F. L. (2002). Teaching and researching reading. New York: Pearson Education.

Guthrie, J., Wigfield, A., Metsala, J. L., \& Cox, K. E. (1999). Motivational and cognitive predictors of text comprehension and reading amount. Scientific Studies of Reading, 3(3), 231-256.

İçmez, S. (2009). Motivation and critical reading in EFL classrooms: a case of ELT preparatory students. Journal of Theory and Practice in Education, 5(2), 123-147.

Kayaoglu, M. N. (2015). Teacher researchers in action research in a heavily centralized education system. Educational Action Research, (23)2, 140-161. doi:10.1080/09650792.2014.997260

Knoll, C. L. (2000). The relationship between motivation and reading comprehension. (Master's Thesis). Retrieved from http://scholarworks.gvsu.edu/theses/497/?utm_source=scholarw orks.gvsu.edu\%2Ftheses\%2F497\&utm_medium=PDF\&utm_campaign=PDFCoverPages

Küçükoğlu, H. (2013). Improving reading skills through effective reading strategies. ProcediaSocial and Behavioral Sciences, 70, $709-714$.

Levine, A., Ferenz, O., \& Reves, T. (2000). EFL academic reading and modern technology: how can we turn our students into independent critical readers?. The Electronic Journal for English as a Second Language, 4(4). Retrieved from http://www.teslej.org/wordpress/issu es/volume4/ej16/ej16a1/

Morgan, R., \& Fuchs, D. (2007). Is there a bidirectional relationship between children's reading skills and reading motivation?. Exceptional Children, 73(2), 165-183.

Ness, M. K. (2009). Reading comprehension strategies in secondary content area classrooms: teacher use of and attitudes towards reading comprehension instruction. Reading Horizons, (49)2, 57-85.

Nuttall, C. (1996). Teaching reading skills in a foreign language (2 ${ }^{\text {nd }}$ ed.). Oxford, UK: Heinemann.

Pachtman, A. B., \& Wilson, K. A. (2006). What do the kids think?. The Reading Teacher, 59(7), 680-684.

Pallant,, J. (2010). SPSS survival manual: A step by step guide to data analysis using SPSS ( th $^{\text {th }}$ ed.). Australia: Allen \& Unwin.

Seider, S. N. \& Lemma, P. (2004). Perceived effects of action research on teachers' professional efficacy, inquiry mindsets and the support they received while conducting projects to intervene into student learning. Educational Action Research, 12(2), 219-38.

Shen, M. Y. (2013). Toward an understanding of technical university EFL learners' academic reading difficulties, strategies, and needs. Electric Journal of Foreign Language Teaching, 10(1), 70-79. 
Shen, M. Y., \& Huang, Y. K. (2002). Collaborative action research for reading strategy instruction: A case in Taiwan. Electronic Journal of Foreign Language Teaching, 4(1), 108-121.

Song, M-J. (1998). Teaching reading strategies in an ongoing EFL university reading classroom. Asian Journal of English Language Teaching, 8, 41-54.

Wyatt, M. (2011). Teachers researching their own practice. ELT Journal 65(4), 417-25.

Yunus, M. M., Salehi, H., \& John, D. S. A. (2013). Using visual aids as a motivational tool in enhancing students' interest in reading literary texts. Recent Advances in Educational Technologies, 114-117. Retrieved from http://arxiv.org/ftp/arxiv/papers/1305/1305.6360.p $\mathrm{df}$

\section{Appendix A. TN2 U10 L4 Reading Text}

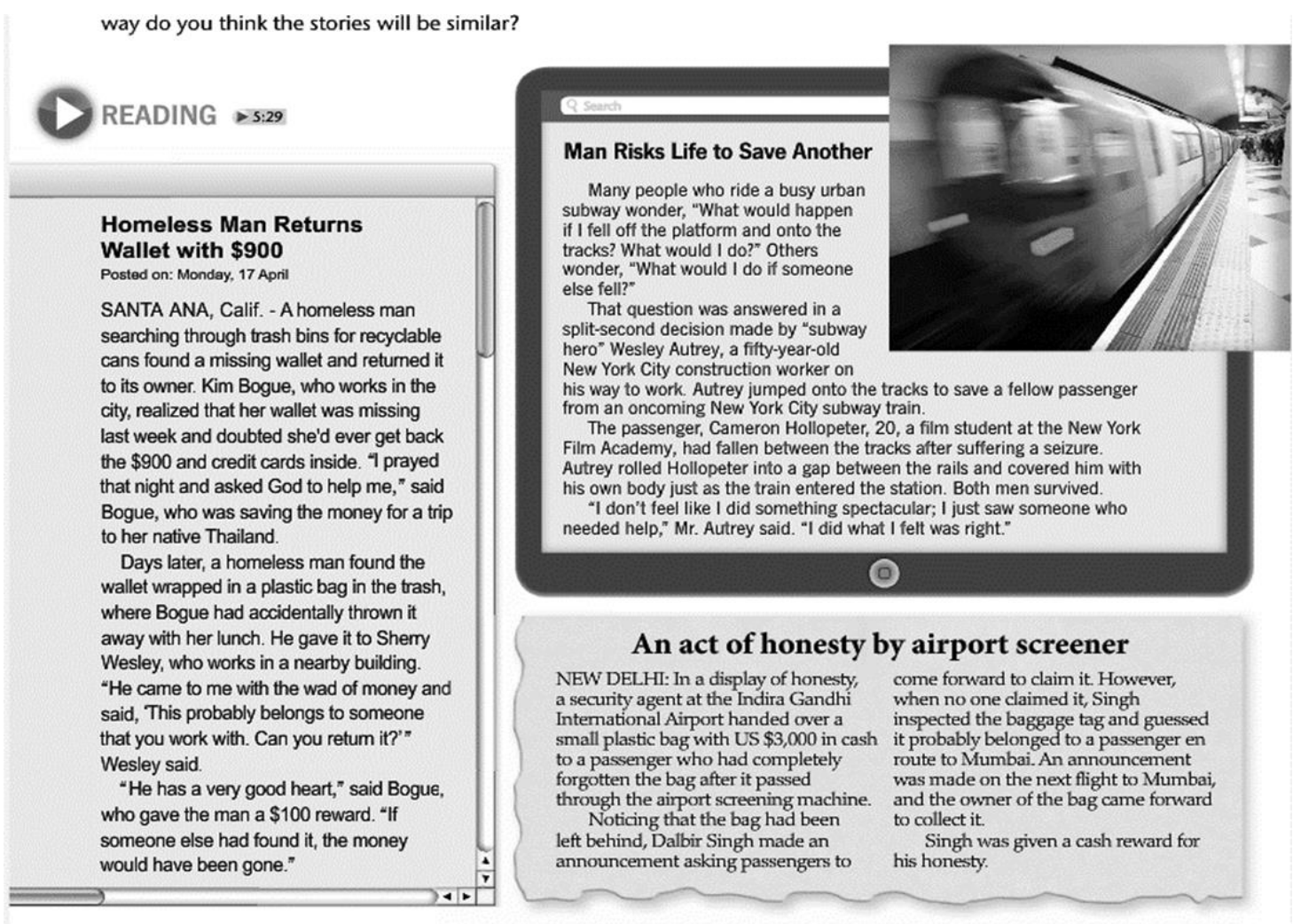

\section{Appendix B. Competition}

1. The man who returned Kim Bogue's wallet was homeless.

2. Kim Bogue was saving her money to go to New York.

3. Bogue believed that whoever found her wallet would return it, including the cash and credit cards inside.

4. Wesley Autrey was saved from an oncoming New York City subway train.

5. The passenger fell between the tracks because he wasn't paying attention.

6. Autrey didn't think of himself as doing anything special 
7. The security agent at an airport in India handed over a wallet with US $\$ 3,000$ in cash.

8. The passenger who lost the money was taking a flight to Mumbai.

9. The security agent was given a cash reward.

10. Why did Kim Bogue give the homeless man a reward?

11. Why did Wesley Autrey risk his life to save a stranger?

\section{Appendix C. TN3 U1 L4}

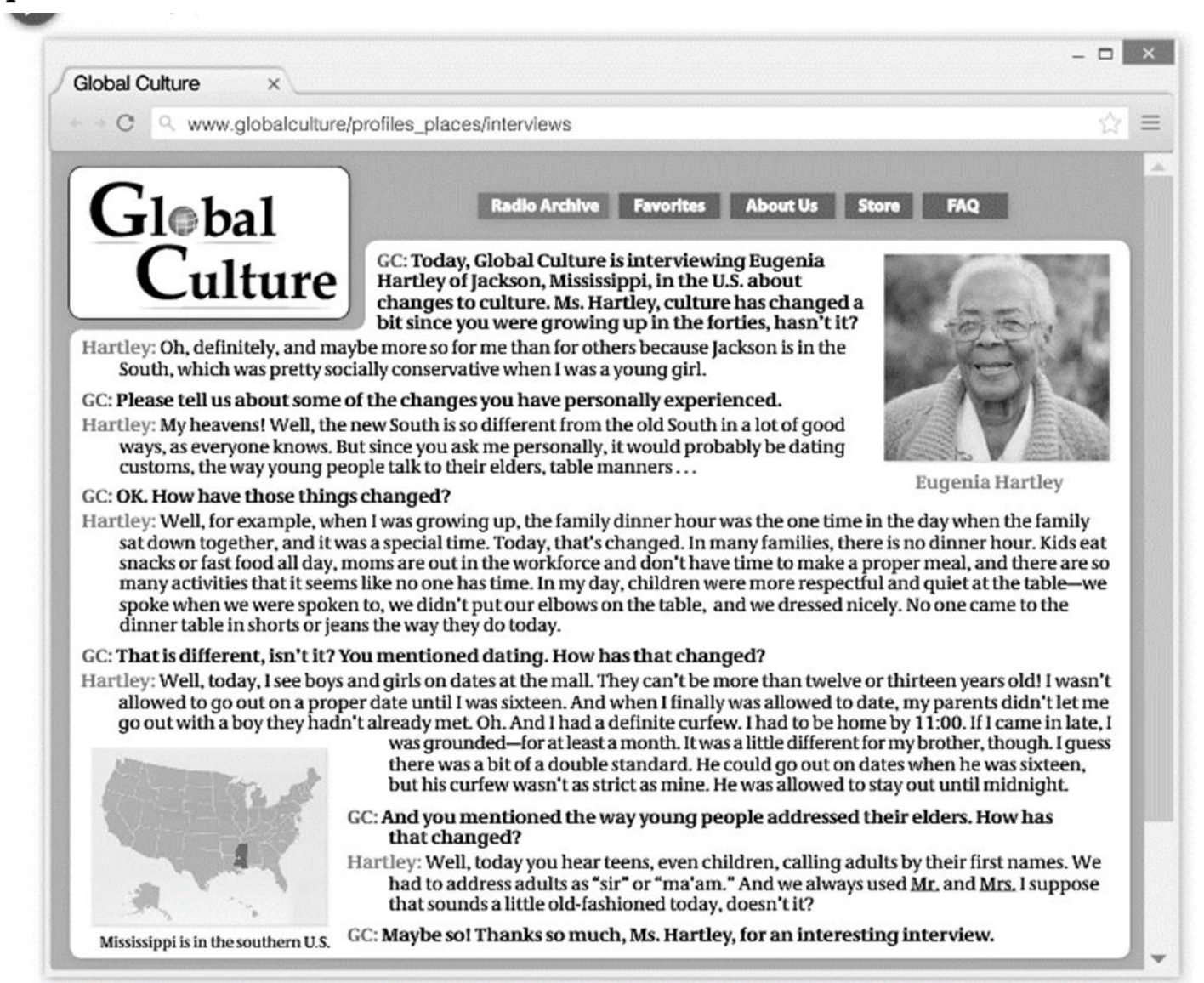

\section{Appendix D. Competition}

1. Ms. Hartley is in her forties.

2. When Ms. Hartley was growing up, children were less polite.

3. When Ms. Hartley was growing up, the main meal was dinner.

4. Both Ms. Hartley and her brother were allowed to date at the age of sixteen.

5. Ms. Hartley didn't use sir or madam with adults; she used Mr. and Mrs

6. Ms. Hartley's upbringing was liberal.

7. The family enforced table manners and etiquette for interacting with adults. 
8. Ms. Hartley's parents believed in disciplining their children if they broke rules.

9. Ms. Hartley didn't date as a teenager.

10. Ms. Hartley's brother had more freedom than she did.

11. The interviewer doesn't think Ms. Hartley sounds a little old-fashioned.

12. How old do you think Ms. Hartley to be today?

13. Does Ms. Hartley prefer the culture of the past or the culture of the present?

14. Is the change in the role of mothers positive or negative?

15. Does she approve of the differences in child and teen behavior that have taken place?

\section{Appendix E. TN3 U2 L3}

\section{Consider the Choices ...}

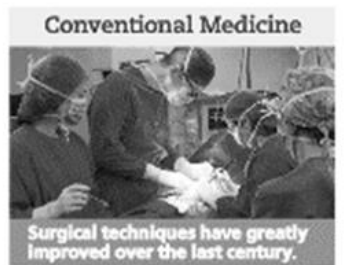

The beginnings of conventional medicine can
be traced back to the fifth century BCE in ancient Greece. it is based on the scientific study of the human body and illness.

In the last century, there has been great progrees in what doctors have been able to do writh modern surgery scientific advances have made conventional medicine the method many people choose first when they need medical first when the
treatments.

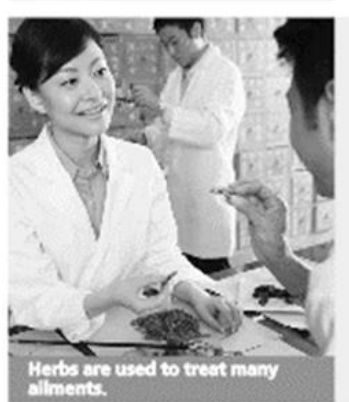

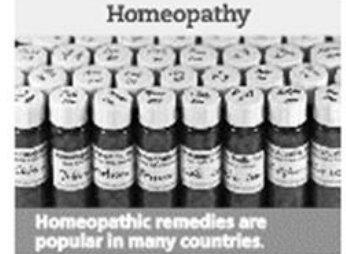

Homeopathy was founded in the late eighteenth century
in Germany. It is a low-cost in Germany. It is a low-cost system of natural medicine
used by hundreds of millions of people worldwide.

In homeopathy, a patient's symptoms are treated with remedies that cause similar symptoms. The remedy is one part remedy to one trillion $(1,000,000,000,000)$ parts prater.

Herbal Therapy

Herbal medicine, often taken as teas or pills, has been practiced for thousands of years in almost all cultures around the world. In fact, many conventional medicines were discovered by cientists studying traditional uses of herbs for medical purposes.

The World Health Organization Thim the of ganization che world's. population uses herbal therap
for their regular health care.

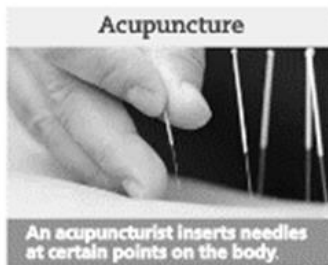

Acupuncture originated in China over 5,000 years ago. Ioday, it is used worldwide fo a variety of problems.

Acupuncture needles are inserted at certain points on the body to retieve pain and/ acupuncture may be effective in helping people stop smoking as weil.

Spiritual Healing

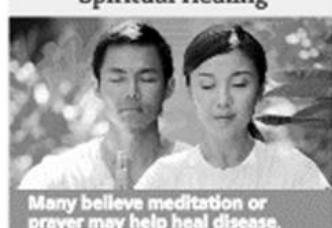

Also known as faith

healing, or "mind and body connection," various forms of spinitual healing exist around the vorld. This is a form of hesiling that uses the mind or religious faith to treat illness.

A number of conventional

doctors say that when they

have not been able to help a

patient, spiri 


\section{Appendix F. Hands-on Activitiy}

an ancient treatment that uses needles to relieve

pain

a method of treatment that uses the mind or religious

faith to treat illnesses

a treatment that uses herbs to treat illnesses

a method of treatment designed to get the body to heal

itself

a treatment based on the scientific study of the human

body and of illnesses

a method of treatment that uses the mind or religious

faith to treat illnesses

\begin{tabular}{l|l|} 
This type of treatment is & This type of treatment \\
based on scientific study & had its beginnings in \\
of the human body & ancient Greece. \\
and illness. & \\
In this type of treatment, & This type of treatment \\
the patient's symptoms are & began in Germany in the \\
treated with remedies that & late 1700s. \\
cause similar symptoms. & \\
\hline 80\% of the world's & In this type of treatment, \\
population uses this & patients take herbs, often \\
type of treatment. & as teas or pills. \\
and & \\
\hline
\end{tabular}

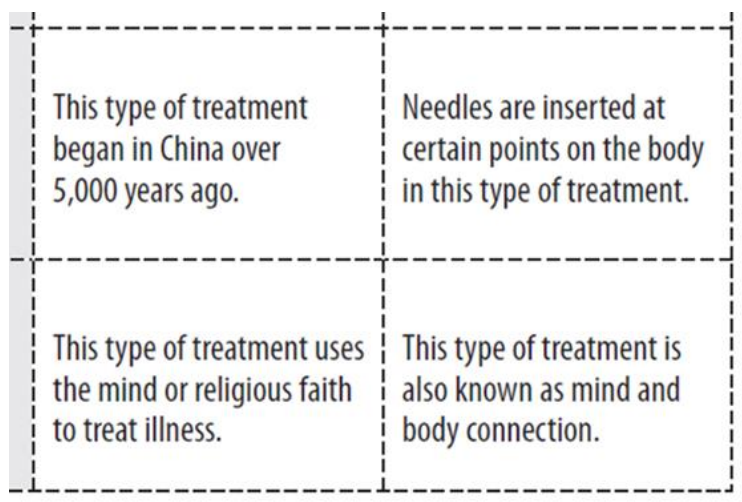

\begin{tabular}{|l|l|l|}
\hline Treatment & What does it use/what is done? & Where did it start? \\
\hline & & \\
& & \\
\hline
\end{tabular}




\section{Appendix G. The works of students}
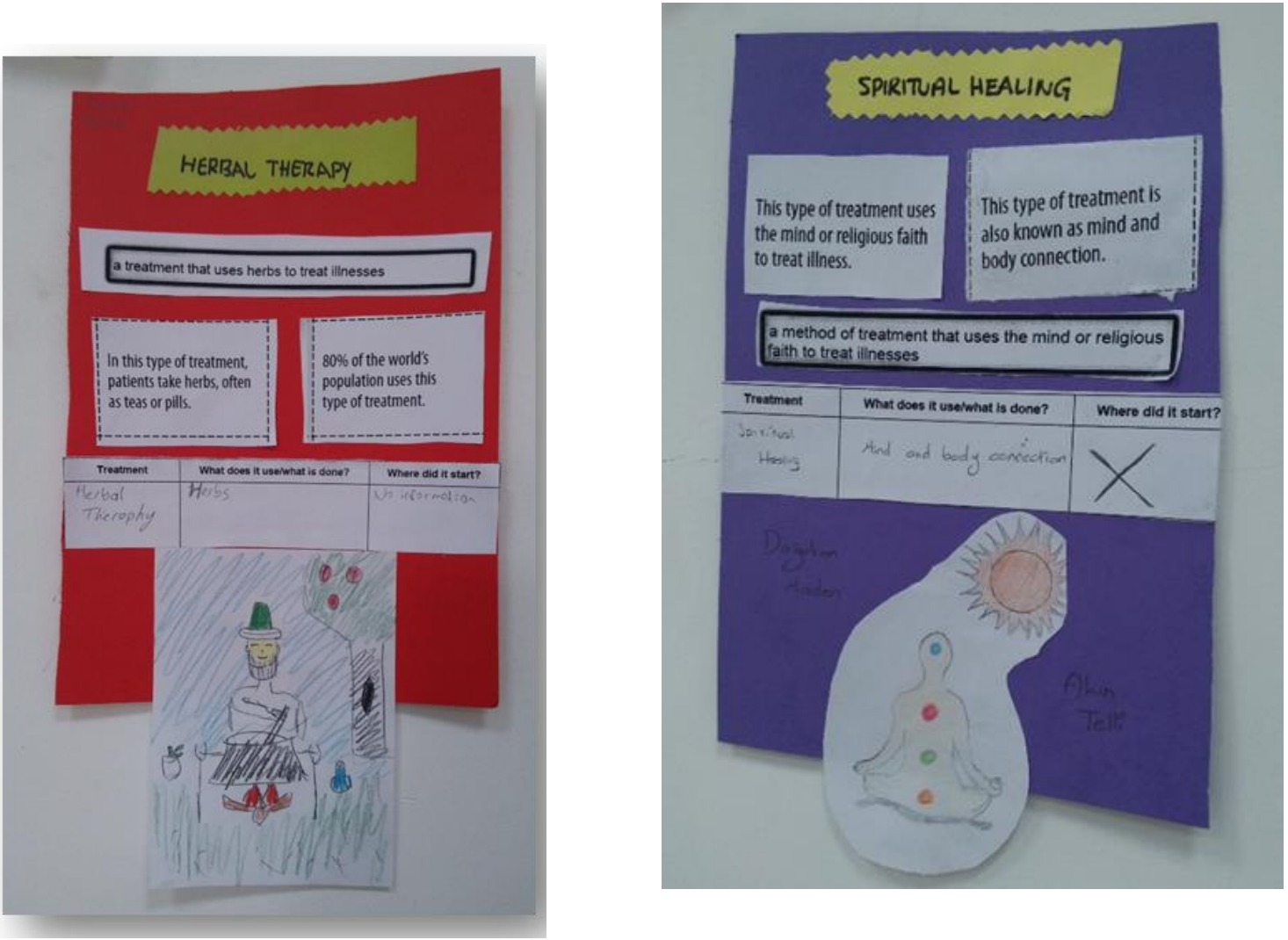

Appendix H. TN3 U7 L3

KEAUING $>$ 4:11

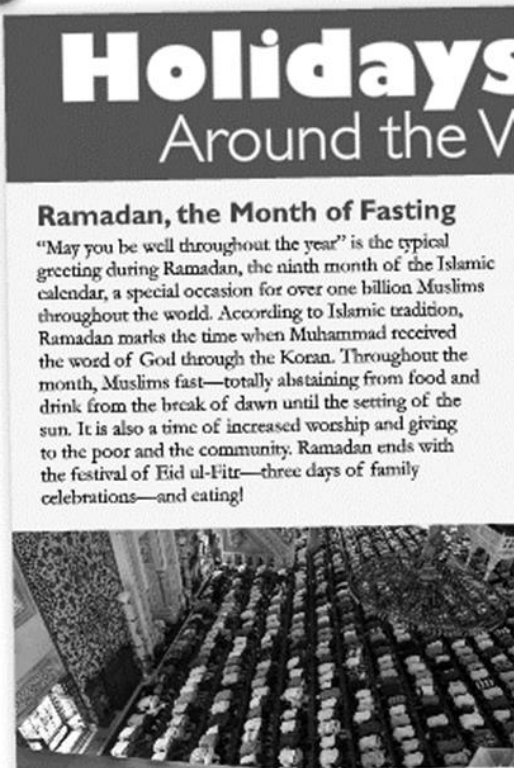

Worstippers pray during Ramadan

The Chinese New Year

The Clinese $\mathrm{New}$ Year is celcbrated by Chinese around the world snd marks the beginning of the first month in the Chinese calcndar. The celcbration usually cakes place in February and lasts for frecn days. Brefore the holiday

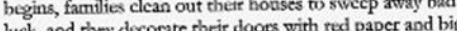
luck, and they deconate their dooss with rod paper and by Chinese characters for happincres werter for a delicious The night before, lamiles gather wa meal. Ouside, people set of fiction

their parents a healthy and happy ney rear and receive red envelopes with money inside. It is customary for poople to give each other small gifts of fruis and swroes and $\mathrm{w}$ visit older famils members. In the stroet, lion and dangon dancers set off more firecrackers to chase away evil spiric

$$
\begin{aligned}
& \text { On the last day. people dance in the } \\
& \text { strect camying a largo doth dragon. }
\end{aligned}
$$

\section{Simón Bolívar's Birthday}

Simbn Bolivar was born on july 24, 1783 , in Caracas Venezuels. He is motvn throughout Latin Amenca "The Liberator" bocause he led the fight for independence from Spain. His armies froed Veneauch Bolivia, Colombia, Ecuador, and Peru. He is memorialized in many ways, but two countric celebratc his birthday every July $24^{\mathrm{t}}-\mathrm{Venezuela}$ and Ecuador. On that day, schools and most genemal busineses are closed, and there are military parades and government ceremonies But the malls are open, and poople usually use the holiday to go shopping

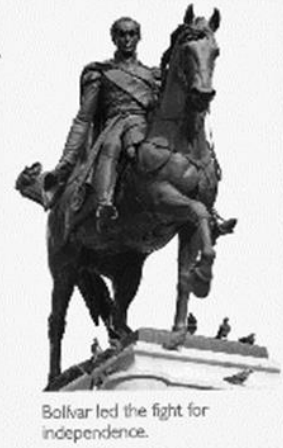




\section{Appendix I. Competition}

\begin{tabular}{|c|c|c|}
\hline $\begin{array}{l}1 \text { True or False: People usually eat } \\
\text { when they have a picnic. }\end{array}$ & $\begin{array}{l}2 \text { A holiday that celebrates a } \\
\text { certain time of the year is a } \\
\text { holiday. } \\
\text { (seasonal) }\end{array}$ & $\begin{array}{l}3 \text { Name one of the two countries } \\
\text { that celebrate the birthday of Simón } \\
\text { Bolivar every year. }\end{array}$ \\
\hline $\begin{array}{l}\text { (1) True or False: People around the } \\
\text { world wish each other well at } \\
\text { midnight on New Year's Eve. }\end{array}$ & $\begin{array}{l}2 \text { Name a holiday on which people } \\
\text { send each other cards. } \\
\text { (Answers will vary.) }\end{array}$ & $\begin{array}{l}3 \text { In which country did mariachi } \\
\text { bands begin? } \\
\text { (Mexico) }\end{array}$ \\
\hline $\begin{array}{l}\text { (1) True or False: In some cultures } \\
\text { it's appropriate to bring a small gift } \\
\text { when you're invited to someone's } \\
\text { house for dinner. } \\
\text { (True.) }\end{array}$ & $\begin{array}{l}2 \text { What is one holiday when people } \\
\text { watch fireworks? } \\
\text { (Answers will vary.) }\end{array}$ & $\begin{array}{l}3 \text { In which country is the hanbok } \\
\text { traditional clothing? }\end{array}$ \\
\hline $\begin{array}{l}(1 \text { True or False: Different countries } \\
\text { celebrate different holiday traditions. }\end{array}$ & $\begin{array}{l}2 \text { What is a woman called at the } \\
\text { time she gets married? }\end{array}$ & $\begin{array}{l}3 \text { What is the traditional } \\
\text { Thanksgiving food in the United } \\
\text { States? }\end{array}$ \\
\hline $\begin{array}{l}\text { (1) True or False: If you get engaged } \\
\text { to someone, then you agree to marry } \\
\text { that person. }\end{array}$ & $\begin{array}{l}(2 \text { What do you call a large formal } \\
\text { party after a wedding ceremony? }\end{array}$ & $\begin{array}{l}3 \text { During the month of Ramadan, } \\
\text { what don't Muslims do during } \\
\text { the day? } \\
\text { (eat or drink) }\end{array}$ \\
\hline $\begin{array}{l}(1 \text { True or False: The Harvest Moon } \\
\text { Festival is a religious holiday. }\end{array}$ & $\begin{array}{l}2 \text { What do you call a vacation taken } \\
\text { by two people who just got married? }\end{array}$ & $\begin{array}{l}3 \text { What do you call a formal } \\
\text { marriage ceremony? }\end{array}$ \\
\hline $\begin{array}{l}\text { (1) True or False: Some people pray } \\
\text { on religious holidays. }\end{array}$ & $\begin{array}{l}2 \text { What is a man called at the time } \\
\text { he gets married? }\end{array}$ & $\begin{array}{l}3 \text { What is the name of the world- } \\
\text { famous holiday celebrated in Rio de } \\
\text { Janeiro, Brazil? }\end{array}$ \\
\hline
\end{tabular}

\section{Copyrights}

Copyright for this article is retained by the author(s), with first publication rights granted to the Journal.

This is an open-access article distributed under the terms and conditions of the Creative Commons Attribution license (CC BY-NC-ND) (http://creativecommons.org/licenses/by-nc-nd/4.0/). 